\title{
Physical Quality Characteristics of Potato (Solanum tuberosum L.) Tubers as Influenced by Cultivar and Plant Spacing in Eastern Ethiopia
}

\author{
${\text { Birhanu Tsegaye } \mathrm{e}^{1^{*}} \quad \text { Nigussie Dechassa }^{2} \quad \text { Wassu Mohammed }}^{2}$ \\ 1. Wolkite University, College of Agriculture and Natural Resource, P O Box 07, Wolkite, Ethiopia \\ 2. Haramaya University, School of Plant Sciences, P O Box 138, Dire Dawa, Ethiopia
}

\begin{abstract}
A field experiment was conducted at Haramaya and Hirna during the main cropping season of 2013 to determine the appropriate plant spacing for potato cultivars in relation to physical tuber quality characteristic. The treatments consisted of five seed tuber spacing between ridges and seed tubers $(75 \mathrm{~cm} \mathrm{x} 30 \mathrm{~cm}, 60 \mathrm{~cm} \times 30 \mathrm{~cm}$, $60 \mathrm{~cm} \times 25 \mathrm{~cm}, 50 \mathrm{~cm} \times 25 \mathrm{~cm}$ and $45 \mathrm{~cm} \times 20 \mathrm{~cm}$ ) and four potato varieties (Bubu, Badhassa, Zemen and Chiro). The experiment was laid out as a randomised complete block design with three replications. All physical quality attributes of potato responded significantly $(\mathrm{P}<0.01)$ for the main effect of variety and spacing. At Haramaya, Bubu had the higher geometric mean diameter $\left(46.76 \mathrm{~mm}^{3}\right)$ and surface area $\left(6958 \mathrm{~mm}^{2}\right)$ of tuber than the other varieties. Tuber sphericity was higher for Bubu (85.28\%), Badhasa (86.54\%) and Chiro (82.26\%). At both locations, wider spacing of $75 \mathrm{~cm} \times 30 \mathrm{~cm}, 60 \mathrm{~cm} \times 30 \mathrm{~cm}$ and $60 \mathrm{~cm} \times 25 \mathrm{~cm}$ gave the highest geometric mean diameter and tuber surface area. However, narrow spacing of $45 \mathrm{~cm} \times 20 \mathrm{~cm}$ and $50 \mathrm{~cm} \times 25 \mathrm{~cm}$ resulted in the higher sphericity of tuber.
\end{abstract}

Keywords: Inter and intra row spacing, Solanum tuberosum L., variety, geometric diameter, sphericity, surface area

DOI: $10.7176 / \mathrm{JAAS} / 52-06$

\section{INTRODUCTION}

Potato (Solanum tuberosum L.) is a crop of major economic importance worldwide. On a global scale, potato is the fourth most cultivated food crop after wheat, rice, and maize (FAOSTAT, 2012). The relatively high carbohydrate and low fat content of potato makes it an excellent energy source for human consumption (Dean, 1994).

Physical characteristics of agricultural products are the most important parameter in the design of grading, handling, processing and packaging systems. Among these physical characteristics, mass, volume, projected area, and centre of gravity are the most important ones in the handling systems (Peleg, 1985). Other important parameters are width, length, and thickness (Peleg, 1985). Knowledge of length, width, volume, surface area and centre location of mass may be applied in the designing of sorting machinery, in predicting surface needed when applying chemicals, shape factor (sphericity), and yield in the peeling operation (surface area) (Wright et al., 1986). Other characteristics worth of concentration are width, length, and thickness (Mohsenin, 1970; Peleg, 1985). Moreover, the appearance of fresh agricultural products is a primary criterion in making purchasing decisions (Kays, 1991).

When tubers are marketed for industrial processing, the portions of certain size-grades and the tuber shape play an important role (Haase et al., 2007). Therefore, the industry processing potatoes demands tubers grade $>$ $50 \mathrm{~mm}$ for French fries and 40 to $65 \mathrm{~mm}$ for crisps. In this connection, the choice of cultivar for industry processing may also be an efficient agronomic measure to increase financial returns when high portions of larger tubers are required Zehra (2011). Tuber shape is an important characteristic in influencing peeling and trimming efficiency during processing (George et al., 2010). Potato tubers that are round (spherical) in shape have been shown to be suitable for crisps processing for most processors because they easily make the required crisp diameters (Kulkarni and Govinden, 1994; Kabira and Lemaga, 2006). The long and oval tubers, however, lend themselves easily for processing of French fries (Kabira and Lemaga, 2006; Abong' et al., 2009).

Factors that influence potato yield and quality include cultivar, soil type, weather conditions, water management, plant population, seed piece size, pests and diseases (Khalafalla, 2001). Plant spacing should depend on type of variety, fertility status of soil, plant architecture or growth habit etc. Potato varieties also differ on growth habit and quality attributes. Therefore, using the same spacing for all varieties may not lead to optimum tuber quality. Thus, this experiment was conducted with the objective of determining some physical quality attributes of potato cultivars under different spacing and growing conditions.

\section{MATERIALS AND METHODS}

Description of Experimental Sites

The study was conducted under rain-fed condition during the 2013 main cropping season at Haramaya and Hirna 
districts, in eastern and western Hararghe zones of the Oromia Regional State in Ethiopia, respectively.

Table 1. Description of the experimental sites

\begin{tabular}{|c|c|c|}
\hline Characteristics /features & Haramaya Site & Hirna Site \\
\hline Latitude & $9^{\circ} 26^{\prime}$ North latitude & $9^{\circ} 12^{\prime}$ North latitude \\
\hline Longitude & $42^{\circ} 3^{\prime}$ East longitude & $41^{\circ} 4^{\prime}$ East longitude \\
\hline Altitude & 2015 masl & 1870 masl \\
\hline Mean annual rainfall & $760 \mathrm{~mm}$ & 990 to $1010 \mathrm{~mm}$ \\
\hline Soil type & well-drained deep alluvial & vertisol \\
\hline Organic carbon content & $1.15 \%$ & $1.75 \%$ \\
\hline Total nitrogen content & $0.11 \%$ & $0.18 \%$ \\
\hline Available Phosphorus content & $18.2 \mathrm{mg} \mathrm{kg} \mathrm{soil}{ }^{-1}$ & $32 \mathrm{mg} \mathrm{kg} \mathrm{soil}{ }^{-1}$ \\
\hline Exchangeable potassium & $0.65 \mathrm{cmolc} \mathrm{kg} \mathrm{soil}^{-1}$ & 0.68 cmolc kg soil $^{-1}$ \\
\hline Soil pH & 8.0 & 7.09 \\
\hline Sand content & $63 \%$ & $27 \%$ \\
\hline Silt content & $20 \%$ & $28 \%$ \\
\hline Clay content & $17 \%$ & $45 \%$ \\
\hline
\end{tabular}

Source; Belay et al., 1998, Tamire, 1973, Simret, 2010, HURC, 1996, Nebret, 2011

\section{Description of Experimental Materials}

The experiment was conducted with four improved potato varieties (Bubu, Badhasa, Zemen and Chiro) which are widely cultivated in eastern Ethiopia.

Table 2. Description of the potato varieties used for the experiment

\begin{tabular}{|c|c|c|c|c|c|c|}
\hline \multirow[b]{2}{*}{ No } & \multirow[b]{2}{*}{ Variety } & \multirow[b]{2}{*}{ Year of release } & \multirow[b]{2}{*}{ Growth habit } & \multirow{2}{*}{$\begin{array}{l}\text { Plant } \\
\text { height } \\
(\mathrm{cm})\end{array}$} & \multicolumn{2}{|c|}{ Area of adaptation } \\
\hline & & & & & $\begin{array}{l}\text { Altitude (metres } \\
\text { above sea level) }\end{array}$ & Rainfall (mm) \\
\hline 1 & Bubu & 2011 & Erect & 66.8 & $1650-2330$ & $700-800$ \\
\hline 2 & Badhasa & 2001 & Erect & $50-55$ & $1700-2000$ & $700-800$ \\
\hline 3 & Zemen & 2001 & Erect & $55-60$ & $1700-2000$ & $700-800$ \\
\hline 4 & Chiro & 1998 & Semi-erect & 60 & $1600-2000$ & $700-800$ \\
\hline
\end{tabular}

Source: MoARD (2012).

\section{Treatments and Experimental Design}

The experiment consisted of four improved potato varieties (Bubu, Badhasa, Zemen and Chiro) and five seed tuber spacing between rows (ridges) and between plants $(75 \mathrm{~cm}$ x $30 \mathrm{~cm}, 60 \mathrm{~cm}$ x $30 \mathrm{~cm}, 60 \mathrm{~cm} \times 25 \mathrm{~cm}, 50 \mathrm{~cm}$ x $25 \mathrm{~cm}$ and $45 \mathrm{~cm} \times 20 \mathrm{~cm}$ ). The treatments were laid out as a randomized complete block design (RCBD) in a factorial arrangement and replicated three times per treatment. Gross plot size was $3.6 \mathrm{~m} \mathrm{x} 4.0 \mathrm{~m}\left(14.4 \mathrm{~m}^{2}\right)$. The spacing between adjacent plots was $1.0 \mathrm{~m}$ and the spacing between adjacent blocks was $1.5 \mathrm{~m}$.

\section{Management of the Experiment}

The experimental fields were cultivated by a tractor and then levelled after which ridges were made by hand. Well-sprouted medium sized seed tubers were planted according to the specified treatments. Cultivation, weeding and harvesting were done at the appropriate time. Untifengicidal chemical (Mancozeb $80 \%$ WP) was applied on 15 days interval at the rate of $1.5 \mathrm{~kg} \mathrm{ha}^{-1}$ diluted at the rate of $40 \mathrm{~g}$ per 20 liter to control late blight disease. Phosphorus fertilizer was applied at the rate of $92 \mathrm{~kg} \mathrm{P}_{2} \mathrm{O}_{5} \mathrm{ha}^{-1}$ was done by banding the granules of DAP (diammonium phosphate) $\left(18 \% \mathrm{~N}, 46 \% \mathrm{P}_{2} \mathrm{O}_{5}\right)$ at the depth of $10 \mathrm{~cm}$ below and around the seed tuber at planting. Nitrogen fertilizer was applied at the rate of $111 \mathrm{~kg} \mathrm{~N} \mathrm{ha}^{-1}$ (Anonymous, 2004).

\section{Data Collection and Measurements}

Geometric mean diameter (Dg) (mm): The size of ten randomly selected tubers from each plot were measured as length, width and thickness using a digital caliper with an accuracy of $0.01 \mathrm{~mm}$. The geometric mean diameter (Dg) was calculated by using the following equation as described by Mohsenin (1970) as cited by Shehzad et al. (2013): $\mathrm{Dg}=(\mathrm{LWT})^{0.333}$

Where, $\mathrm{L}$ is the length; $\mathrm{W}$ is the width and $\mathrm{T}$ is thickness of the tuber.

Sphericity of the tuber $(\Phi)(\%)$ : Tuber sphericity was determined by the following formula as described by Ahmadi et al. (2008): $\Phi=(\mathrm{Dg} / \mathrm{L}) \times 100$

Where, $\Phi$ is sphercity of the tuber, Dg is geometric mean diameter and $\mathrm{L}$ is length

Surface area (S) $\left(\mathbf{m m}^{2}\right)$ : Tubers surface area was determined according to Baryeh (2001) by the following formula: $\mathrm{S}=\pi \mathrm{Dg}^{2}$ 
Where, $\mathrm{S}$ is surface area and $\mathrm{Dg}$ is geometric mean diameter

\section{Data Analysis}

The data were subjected to analysis of variance (ANOVA) using the General Linear Model of the SAS statistical package (SAS, 2007) version 9.1. All significant pairs of treatment means were compared using Tulkey Test at $5 \%$ level of significance. T-test was conducted to determine differences between the two locations in the performance of the potato varieties to plant spacing. F-test was computed for determining homogeneity of variance for the locations.

\section{RESULTS AND DISCUSSION}

\section{Geometric mean diameter}

The main effects of variety and seed tuber spacing significantly $(\mathrm{P}<0.01)$ affected geometric mean diameter of the tuber at both locations. However, variety and plant spacing did not interact to influence this parameter at both locations (Appendix Table 1, 2 and 3).

At Haramaya, Bubu had the highest geometric mean diameter $\left(46.76 \mathrm{~mm}^{3}\right)$ than the other varieties; whereas the other varieties are in statistical parity with each other. However, at Hirna, Bubu, Zemen and Chiro had higher geometric mean diameters $\left(50.49,49.34\right.$ and $49.11 \mathrm{~mm}^{3}$, respectively) while Badhasa had the lower $\left(45.83 \mathrm{~mm}^{3}\right)$. This is because of the production of large-sized tubers by Bubu, Zemen and Chiro varieties which resulted in high geometric mean diameter. Increasing plant spacing significantly increased geometric mean diameter. Thus, in general, $75 \mathrm{~cm} \times 30 \mathrm{~cm}, 60 \mathrm{~cm} \times 30 \mathrm{~cm}$ and $60 \mathrm{~cm} \times 25 \mathrm{~cm}$ spacing resulted in higher geometric mean diameters compared to $45 \mathrm{~cm} \times 20 \mathrm{~cm}$ and $50 \mathrm{~cm} \times 25 \mathrm{~cm}$ spacing. This is because large-sized tubers are produced in response to wider spacing than narrower spacing, consequently resulted in higher geometric mean diameters (Table 14). Habtamu (2013) indicated that geometric mean diameter of potato was significantly influenced by variety and growing environment.

\section{Sphericity of tuber}

The main effects of variety and spacing significantly $(\mathrm{P}<0.01)$ affected sphericity of tubers produced at both locations and the mean results of the locations. However, the interaction effect of variety and spacing did not influence this parameter at both locations (Appendix Tables 1, 2and 3).

Mean result of the two locations showed that Bubu, Badhasa and Chiro are more spherical in shape as compared to Zemen. On the other hand, decreasing plant spacing significantly increased tuber sphericity. More spherical tubers were obtained from narrow spacing of $45 \mathrm{~cm} \times 20 \mathrm{~cm}(94.09 \%)$ and $50 \mathrm{~cm} \times 25 \mathrm{~cm}(89.38 \%)$ (Table 14). This is because at narrower spacing, small-sized tubers are produced which are more or less spherical in shape as compared to tubers that are produced in response to wider spacing, which are usually wide and large in size and oval in shape.

The t-test of sphericity of the overall mean of the two locations revealed a non-significant difference. This indicates that tuber sphericity did not influenced by varied environmental factors across the locations.

\section{Surface area}

Both the main effects of variety and plant spacing significantly $(\mathrm{P}<0.01)$ influenced surface area of potato tubers at both locations. However, the interaction effect of variety and plant spacing did not influence this parameter at both locations (Appendix Tables 1, 2 and 3).

At Haramaya, Bubu had the highest tuber surface area $\left(6958 \mathrm{~mm}^{2}\right)$, while the remaining varieties had the lowest surface area and were in statistical parity with each other. However, under Hirna condition, the varieties Bubu, Zemen and Chiro had higher surface area of $\left(8055,7676\right.$ and $7622 \mathrm{~mm}^{2}$, respectively). Consistent with the results of this study, Habtamu (2013) observed significant varietal and location differences for surface area of potato tubers. Increasing seed tuber spacing significantly increased surface area of potato tuber. Thus, at both locations, spacing of $75 \mathrm{~cm} \times 30 \mathrm{~cm}, 60 \mathrm{~cm} \times 30 \mathrm{~cm}$ and $60 \mathrm{~cm} \times 25 \mathrm{~cm}$ resulted in the highest surface area while spacing of $45 \mathrm{~cm} \times 20 \mathrm{~cm}$ and $50 \mathrm{~cm} \times 25 \mathrm{~cm}$ led to the lowest surface area (Table 14). This is because at wider spacing large-sized tubers are produced which have higher surface area due to less stiffer competition for resources whereas at narrow spacing small-sized tubers are produced due to stiffer competition for growth factors. 
Table 3. Geometric mean diameter, sphericity and Surface area of potato tubers as influenced by the main effects of variety and spacing at Haramaya and Hirna during the 2013 main cropping season.

\begin{tabular}{|c|c|c|c|c|c|c|c|}
\hline \multirow[b]{2}{*}{ Variety } & \multicolumn{2}{|c|}{$\begin{array}{l}\text { Geometric mean diameter } \\
\left(\mathrm{mm}^{3}\right)\end{array}$} & \multicolumn{2}{|c|}{ Sphericity of tuber $(\%)$} & \multirow[b]{2}{*}{ Mean } & \multicolumn{2}{|c|}{ Surface area $\left(\mathrm{mm}^{2}\right)$} \\
\hline & Haramaya & Hirna & Haramaya & Hirna & & Haramaya & Hirna \\
\hline Bubu & $46.76 \mathrm{a}$ & $50.49 a$ & $85.58 \mathrm{ab}$ & $84.99 \mathrm{ab}$ & $85.28 \mathrm{a}$ & $6958 \mathrm{a}$ & $8055 a$ \\
\hline Badhasa & $37.64 b$ & $45.83 b$ & $86.04 \mathrm{a}$ & $87.04 \mathrm{a}$ & $86.54 \mathrm{a}$ & $4588 b$ & $6663 b$ \\
\hline Zemen & $37.55 b$ & $49.34 \mathrm{ab}$ & $78.39 b$ & $79.55 c$ & $78.97 b$ & $4562 b$ & $7676 \mathrm{ab}$ \\
\hline Chiro & $41.14 b$ & $49.11 \mathrm{ab}$ & $82.14 \mathrm{ab}$ & $82.37 b c$ & $82.26 \mathrm{ab}$ & $5367 b$ & $7622 \mathrm{ab}$ \\
\hline $\operatorname{LSD}(0.05)$ & 3.461 & 2.662 & 5.543 & 3.107 & 3.454 & 839.3 & 770.2 \\
\hline F-test & $* *$ & $* *$ & $*$ & $* *$ & $* *$ & $* *$ & $* *$ \\
\hline $\mathrm{CV} \%$ & 11.5 & 7.4 & 9 & 5 & 5.6 & 21.1 & 13.9 \\
\hline \multicolumn{8}{|l|}{ Spacing } \\
\hline $75 \mathrm{~cm} \mathrm{x} 30 \mathrm{~cm}$ & $44.95 \mathrm{a}$ & $52.56 \mathrm{a}$ & $76.27 \mathrm{c}$ & $71.27 \mathrm{e}$ & $73.77 \mathrm{c}$ & $6506 a$ & $8682 a$ \\
\hline $60 \mathrm{~cm} \times 30 \mathrm{~cm}$ & $43.35 \mathrm{ab}$ & $49.23 \mathrm{ab}$ & $77.81 \mathrm{c}$ & $76.30 \mathrm{~d}$ & $77.05 \mathrm{bc}$ & $6073 a$ & $7651 \mathrm{ab}$ \\
\hline $60 \mathrm{~cm} \times 25 \mathrm{~cm}$ & $41.34 \mathrm{abc}$ & $48.91 \mathrm{ab}$ & $81.38 b c$ & $82.65 c$ & $82.02 b$ & $5433 \mathrm{ab}$ & $7569 \mathrm{ab}$ \\
\hline $50 \mathrm{~cm} \times 25 \mathrm{~cm}$ & $38.05 \mathrm{bc}$ & $46.99 \mathrm{~b}$ & $87.86 \mathrm{ab}$ & $90.90 \mathrm{~b}$ & $89.38 \mathrm{a}$ & $4632 b$ & $6975 b$ \\
\hline $45 \mathrm{~cm} \mathrm{x} 20 \mathrm{~cm}$ & $36.15 c$ & $45.77 b$ & $91.87 \mathrm{a}$ & $96.31 \mathrm{a}$ & $94.09 \mathrm{a}$ & $4199 b$ & $6643 b$ \\
\hline LSD (0.05) & 3.87 & 2.976 & 6.197 & 3.474 & 3.862 & 938.4 & 861.1 \\
\hline F-test & $* *$ & $* *$ & $* *$ & $* *$ & $* *$ & $* *$ & $* *$ \\
\hline $\mathrm{CV} \%$ & 11.5 & 7.4 & 9 & 5 & 5.6 & 21.1 & 13.9 \\
\hline \multicolumn{8}{|l|}{ Overall mean } \\
\hline Location & 40.77 & 48.69 & 83.04 & 83.49 & & 5369 & 7504 \\
\hline T-test & $* *$ & & NS & & & $* *$ & \\
\hline $\operatorname{LSD}(0.05)$ & 1.5 & & 2.181 & & & 391.4 & \\
\hline
\end{tabular}

Means followed by the same letter within a column for the main effects of variety and plant spacing are not significantly different at $5 \%$ level of significance. $* *=$ significant at $1 \%$ probability level, $*=$ significant at $5 \%$ probability level. NS= non-significant difference. $\mathrm{LSD}=$ Least significant difference; $\mathrm{CV} \%=$ Coefficient of variation and $\mathrm{NS}=$ non-significant difference.

\section{SUMMARY AND CONCLUSION}

The experiment was conducted out at Haramaya and Hirna, Hararghe highlands of Eastern Ethiopia. Randomized complete black design in factorial arrangement was used with three replications which comprised of five levels of plant spacing $(75 \mathrm{~cm} \times 30 \mathrm{~cm}, 60 \mathrm{~cm} \times 30 \mathrm{~cm}, 60 \mathrm{~cm} \times 25 \mathrm{~cm}$ and $50 \mathrm{~cm} \times 25 \mathrm{~cm}$ and $45 \mathrm{~cm} \times$ $20 \mathrm{~cm}$ ) and four levels potato varieties (Bubu, Badhassa, Zemen and Chiro). All physical quality attributes of potato responded significantly $(\mathrm{P}<0.01)$ for the main effect of variety and spacing. At Haramaya, Bubu had the higher geometric mean diameter $\left(46.76 \mathrm{~mm}^{3}\right)$ and surface area $\left(6958 \mathrm{~mm}^{2}\right)$ of tuber than the other varieties. Spericity of tuber was higher for Bubu (85.28\%), Badhasa $(86.54 \%)$ and Chiro $(82.26 \%)$. At both locations, the wider spacing of $75 \mathrm{~cm} \times 30 \mathrm{~cm}$ and $60 \mathrm{~cm} \times 30 \mathrm{~cm}$ and $60 \mathrm{~cm} \times 25 \mathrm{~cm}$ gave the highest geometric mean diameter and tuber surface area. However, narrow spacing (high planting density) of $45 \mathrm{~cm} \times 20 \mathrm{~cm}$ and $50 \mathrm{~cm}$ $\mathrm{x} 25 \mathrm{~cm}$ resulted in the higher sphericity of tuber.

\section{Acknowledgement}

\section{REFERENCES}

Abong', G.O., Okoth, M.W., Karuri, E.G., Kabira, J.N. and Mathooko, F.M. 2009. Levels of reducing sugars in eight Kenyan potato cultivars as influenced by stage of maturity and storage conditions. Journal of Animal and Plant Science 2 (2): pp. 76 - 84.

Ahmadi, H., Fathollahzadeh, H., Mobli, H. 2008. Some Physical and Mechanical Properties of Apricot Fruits, Pits and Kernels (C.V Tabarzeh). American-Eurasian Journal of Agricultural and Environmental Sciences 3(5), pp. 703-707.

Anonymous. 2004. Directory of Released Crop Varieties and Their Recommended Cultural Practices. Ethiopian Agricultural Research Organization, Addis Ababa, Ethiopia.

Baryeh, E.A. 2001. Physical properties of Bambara groundnuts. Journal of Food Engineering 47: pp. 321-326.

Belay, S., Wortman, W., and Hoogen boom, G. 1998. Haricot bean agro-ecology in Ethiopia: definition using agro-climatic and crop growth stimulation models. African Crop Science Journal 6: pp. 9-18.

Dean, B.B. 1994. Managing the Potato Production System. Food Products Press, USA, 61p.

FAOSTAT. 2012. Food and Agriculture Organization of the United Nations, for a world without hunger. Rome, Italy. http://faostat.fao.org /site/567/. 
George, O. Abong, Michael, W. Okoth, Jasper, K. Imungi and Jackson N. Kabira. 2010. Evaluation of selected Kenyan potato cultivars for processing into potato Crisps. Agriculture and biology journal of America 1(5): pp 886-893.

Haase, T., Schüler, C., and Heb, J. 2007. The effect of different N and K sources on tuber nutrient uptake, total and graded yield of potatoes (Solanum tuberosum L.) for processing. European Journal of Agronomy, 26: pp. 187-197.

Habtamu Gebreselassie. 2013. Evaluation of physicochemical and processing attributes of potato (Solanum tuberosum L.) varieties in Eastern Ethiopia. Unpublished MSc. Thesis submitted to school of plant sciences, Haramaya University, Ethiopia.

HURC (Haramaya University Research Centre). 1996. Proceedings of the $13^{\text {th }}$ annual Research and extension review meeting. pp. 26-28.

Kabira, J.N., and Lemaga, B. 2006. Potato Processing: Quality Evaluation procedures for research and food industries applications in East and Central Africa. Kenya Agricultural Research Institute, Nairobi, Kenya.

Kays, S. J. 1991: Postharvest physiology of perishable plant products. New York: Van Nostrand Reinholt.

Khalafalla, A. M. 2001. Effect of plant density and seed size on growth and yield of Solanum potato in Khartoum state, Sudan. African Crop Science Journal Vol. 9, No. 1: pp. 77-82.

Kulkarni, K.D, and Govinden, N. 1994. Crisp Quality of Two Potato Varieties: Effects of Dehydration and Rehydration. J Sci. Food Agric. 64 (2): pp. 205-210.

MoARD (Ministry of Agriculture and Rural Development). 2012. Animal and Plant Health Regulatory Directorate. Crop Variety Register Issue No. 12. Addis Ababa, Ethiopia. p. 180.

Mohsenin, N.N. 1970. Physical properties of plant and animal material. New York. Gordon and Breach.

Nebret Tadesse. 2011. The effect of Nitrogen and Sulphur on yield and yield component of common bean in Eastern Ethiopia. Unpublished M.Sc. Thesis presented to the school of graduate studies of Haramaya University. 25p.

Peleg K. 1985. Produce handling, packaging, and distribution. The AVI Publishing Company. Inc. Westport, Connecticut, pp. 55-95.

SAS (Statistical Analysis Software). 2007. Stat. Jahrbuch tuber Ernahrung, Landwirtschaft und Forsten In German, Landwirtschaftsverlag Munster-Hiltrup, Germany, 2008.

Shehzad Hussain, Tariq Masud1, Sartaj Ali, Rahat Bano, Amjad Ali. 2013. Some physico-chemical attributes of pear (Pyrus communis L.) cultivars grown in Pakistan. International Journal of Biosciences. Vol. 3, No. 12 , pp. 206-215.

Simret Burga. 2010. Influence of inorganic nitrogen and potassium fertilizers on seed tuber yield and size distribution of potato (Solanum tuberosum L.). MSc. Thesis submitted to school of plant sciences, Haramaya University, Ethiopia.

Tamire Hawando. 1973. Characterization of Alemaya Soils. Soil Science Paper, Series No, 1. p. 45.

Wright Malcom, E., Tappan, J. H. and Sister, F. E. 1986. The size and shape of typical sweet potatoes. Transactions of the ASAE, 29 (3), pp. 678-68.

Zehra, E. 2011. Some analytical quality characteristics for evaluating the utilization and consumption of potato (Solanum tuberosum L.) tubers. African Journal of Biotechnology Vol. 10(32), pp. 6001-6010.

\section{APPENDIX TABLE}

Appendix Table 1. Mean squares from analysis of variance (ANOVA) for some tuber quality attributes at Haramaya site

\begin{tabular}{llllll}
\hline Variables & Replication & Variety $(\mathrm{V})$ & Spacing $(\mathrm{S})$ & $\mathrm{V}$ x S & Error \\
\hline Degrees of freedom & 2 & 3 & 4 & 12 & 38 \\
Geometric mean diameter & 13.72 & $280.81^{* *}$ & $159.6^{* *}$ & $34.58 \mathrm{~ns}$ & 21.93 \\
Sphericity of tuber & 23.03 & $189.2^{*}$ & $531.58^{* *}$ & $20.63 \mathrm{~ns}$ & 56.22 \\
Surface area & 960543 & $18926975^{* *}$ & $11110773^{* *}$ & $2073641 \mathrm{~ns}$ & 1289236 \\
\hline
\end{tabular}

Appendix Table 2. Mean squares from analysis of variance (ANOVA) for some tuber quality attributes at Hirna site

\begin{tabular}{llllll}
\hline Variables & Replication & Variety $(\mathrm{V})$ & Spacing $(\mathrm{S})$ & $\mathrm{V}$ x S & Error \\
\hline Degrees of freedom & 2 & 3 & 4 & 12 & 38 \\
Geometric mean diameter & 21.88 & $60.2^{* *}$ & $80.4^{* *}$ & $7.64 \mathrm{~ns}$ & 12.97 \\
Sphericity of tuber & 25.66 & $158.08^{* *}$ & $1263.47^{* *}$ & $21.75 \mathrm{~ns}$ & 17.66 \\
Surface area & 1772568 & $5268714^{* *}$ & $7309073^{* *}$ & $653607 \mathrm{~ns}$ & 1085611 \\
\hline
\end{tabular}


Appendix Table 3. Mean squares from analysis of variance (ANOVA) for some tuber quality attributes for the mean of the two locations

\begin{tabular}{llllll}
\hline Variables & Replication & Variety $(\mathrm{V})$ & Spacing $(\mathrm{S})$ & $\mathrm{V} \times \mathrm{S}$ & Error \\
\hline Degrees of freedom & 2 & 3 & 4 & 12 & 38 \\
Geometric mean diameter & 17.131 & $129.828^{* *}$ & $113.796^{* *}$ & $11.091 \mathrm{~ns}$ & 7.262 \\
Sphericity of tuber & 24.08 & $171.22^{* *}$ & $854.88^{* *}$ & $9.28 \mathrm{~ns}$ & 21.83 \\
Surface area & 1317716 & $9528818^{* *}$ & $8871981^{* *}$ & $653603 \mathrm{~ns}$ & 499052 \\
\hline
\end{tabular}

